\title{
PREPARATION AND APPLICATION OF VIRAL MATERIAL, IN BIOLOGICAL CONTROL OF THE JACK PINE SAWFLY ${ }^{1}$
}

\author{
By W. A. SMIRNOFF"
}

Dr. W. A. Smirnoff completed all his formal education in Europe where he obtained B.A., F.E. and Ph.D. degrees. For a period of 11 years he conducted for the Department of Agriculture of Morocco, intensive researches on the biological control of citrus insects. In 1957 he obtained a D.Sc. degree from the University of Paris and emigrated to Canada to undertake research in insect pathology at the Forest Entomology and Pathology Laboratory of the Canada Department of Forestry, at Quebec.

\section{RESUME}

Des recherches tant en laboratoire que dans la nature ont permis d'obtenir des renseignements détaillés sur le comportement d'un virus polyédrique causant une maladie chez les larves de la mouche-à-scie du pin gris (Neodiprion swainei Midd.). Elles ont servi également à mettre au point une méthode pratique pour l'utilisation de cette virose comme moyen de lutte biologique contre cette dangereuse tenthrède. D'excellents résultats ont été obtenus lorsqu'une suspension du virus a été répandue du haut des airs à l'aide d'avions.

Le présent travail donne des indications pratiques pour obtenir en grande quantité la matière virale et sur divers procédés pour son application. La multiplication du virus se fait par infection des larves réalisée "per os" en pulvérisant sur le feuillage une suspension aqueuse de polyèdres. Les techniques pour l'extraction et la purification des polyèdres sont expliquées en détail. La suspension virale peut être conservée pendant plusieurs années à une température d'environ $4^{\circ} \mathrm{C}$. et un $\mathrm{pH}$ de 6 ou 7 .

Lorsqu'on désire obtenir la destruction complète et rapide de l'insecte dans un peuplement, les arbres doivent être complètement aspergés. On obtient des résultats plus lents, soit en 3 ou 4 années, en pulvérisant par tache ou en relachant des femelles issues de larves faiblement malades et qui ont réussi à compléter leur développement; les femelles transmettent la maladie à leur progéniture.

\footnotetext{
${ }^{1}$ Department of Forestry of Canada, Forest Entomology and Pathology Branch Contribution No. 1017.

${ }^{9}$ Research Officer, Forest Research Laboratory, P.O. Box 35, Sillery, Quebec, Canada.
} 


\section{INTRODUCTION}

The jack pine sawfly, Neodiprion swainei Midd., is a serious defoliator of jack pine, Pinus banksiana Lamb., capable of attaining epidemic numbers over large areas. It has been known to kill extensive stands of jackpine in eastern Canada (Fig. 1 (A)), and create serious fire hazards. Recently it was demonstrated (Smirnoff, 1961) that the sawfly can be controlled successfully with a nucleopolyhedrosis virus which attacks the insect.

This paper presents methods for preparing large quantities of viral material for spraying purposes, and means of application.

\section{LifE CyCLE}

$N$. swainei hibernates in cocoons in the litter of the soil. Adults usually emerge at the end of June. Eggs are laid in the current year's needles and are usually visible 4 to 8 days before hatching, due to a swelling and browning of the needles. Under normal weather conditions hatching occurs during the first or second week of July. The young larvae in colonies of 60 to 120 move down the twigs to feed on the previous year's foliage. Normally, by the beginning of September, larvae attain the 5th instar (Fig. 1b), transform to prepupae, fall to the soil, and spin cocoons. In periods of heavy attack starved larvae will eat all foliage, including that of the current year. When in search of food, larvae may migrate to nearby trees by crawling down the trunk or by dropping to the ground, and then searching for jack pine trees with foliage (Smirnoff, 1960).

\section{The Virus Disease}

This nucleopolyhedrosis was first recorded in Canada in 1953 by Dr. F. T. Bird, Insect Pathology Research Institute, Sault Ste. Marie, Canada. The development and other phases of this disease have subsequently been studied by the author (Smirnoff, 1961). The virus develops in the nuclei of the mid-gut epithelial cells of the host larvae. Under the electron microscope viral particles appear as rods measuring about 50 millimicrons (Fig. 1 (d)). These particles are encrusted in protein agglomerations which are polyhedral in form and measure from 0.5 to 1.7 microns (Fig. 1 (c) ). Therefore, they are readily observed under dark field with contrast phase objectives.

Three or four days after feeding on foliage sprayed with a suspension of polyhedral virus, the larvae lose their appetite. At this time coagulation of the chromatin can be observed in the nuclei of cells of the mid-gut epithelium, followed later by a formation of new polyhedra. Progress of the disease depends on the larval stages but usually lasts from 10 to 17 days. First-, second-, and third-instar larvae are more sensitive. Temperatures between 22 and $30^{\circ} \mathrm{C}$ are optimal for the development of viral infection.

\section{Collection of LaRvae in the Forest}

Dead larvae often stick to the foliage and upon drying become partially disintegrated (Fig. 1 (e) ). Tests have shown that artificial infection of larvae in the forest for virus production is not very successful, since mortality occurs during migration, and most of the dead larvae fall to the ground or are washed away by rain. Therefore, the production of this virus necessitates controlled rearing of large numbers of larvae selected in the forest. Mass collections of larvae should be made in an area heavily infested by $N$. swainei. The 


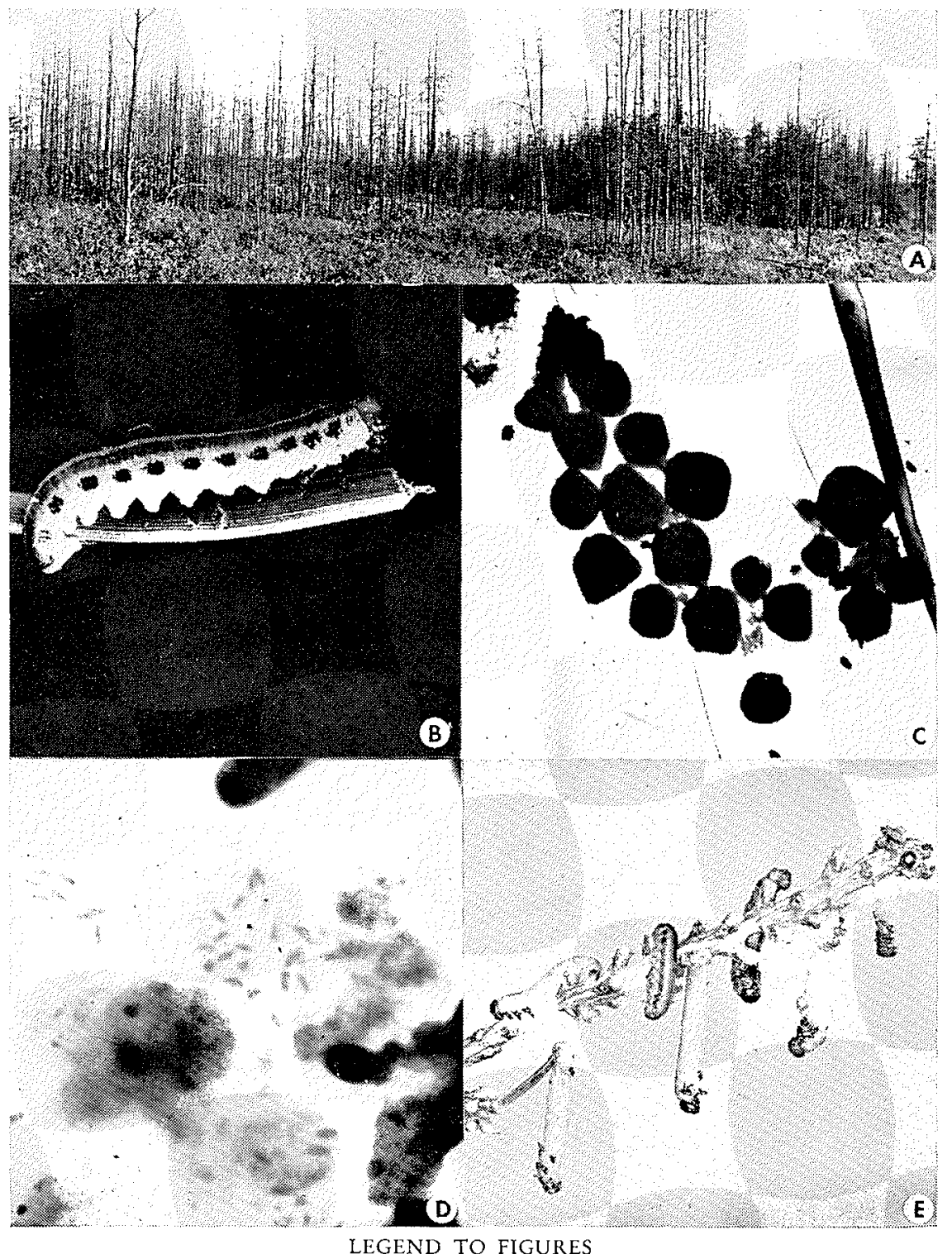

FIGURE 1. A) Jack pine stand severely defoliated by N. stuainci;

B) Larvac of $N$. swainei;

C) Electron micrograph of polyhedra isolated from killed larvae of $N$. swainct

D) Elecrron micrograph of polyhedra partially dissolved, showing virus particles $-\mathrm{X} 20,000$

E) N. swainci larvae killed by the virus diseasc. 

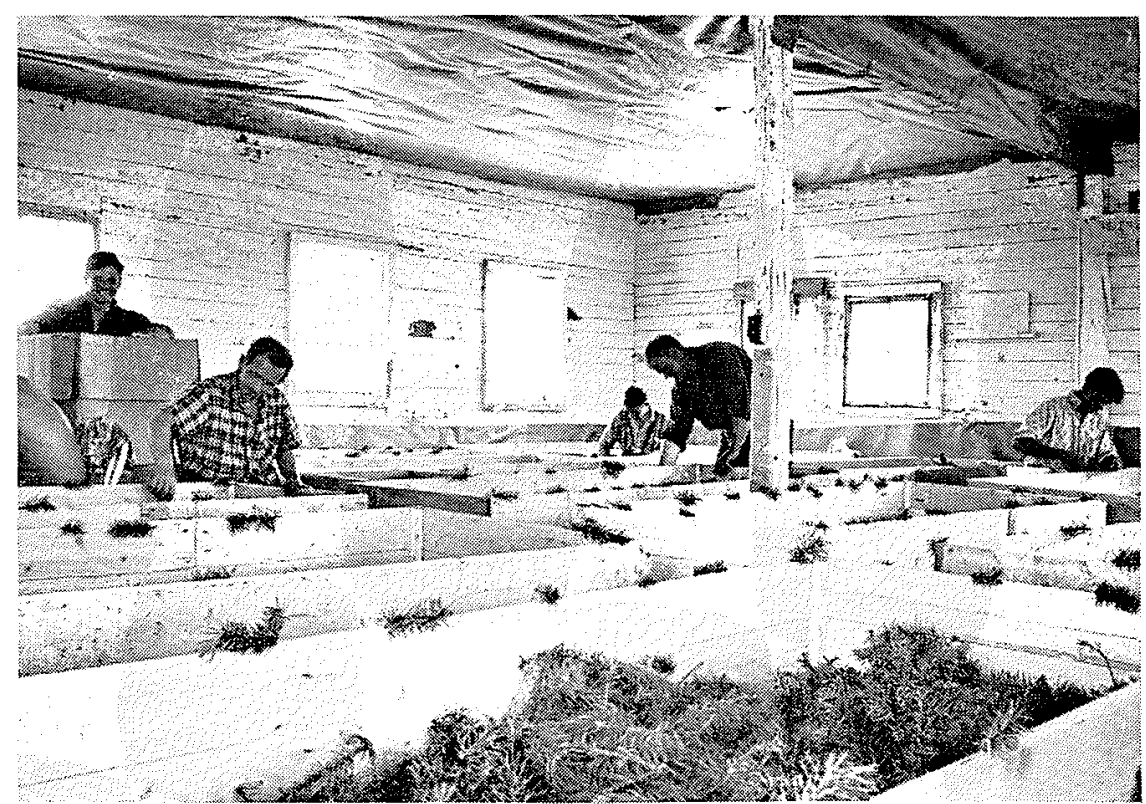

FIGURE 2. Trays for mass rearings of larvae (on the edge of cach tray, twigs arc attached to catch migracing larvae).

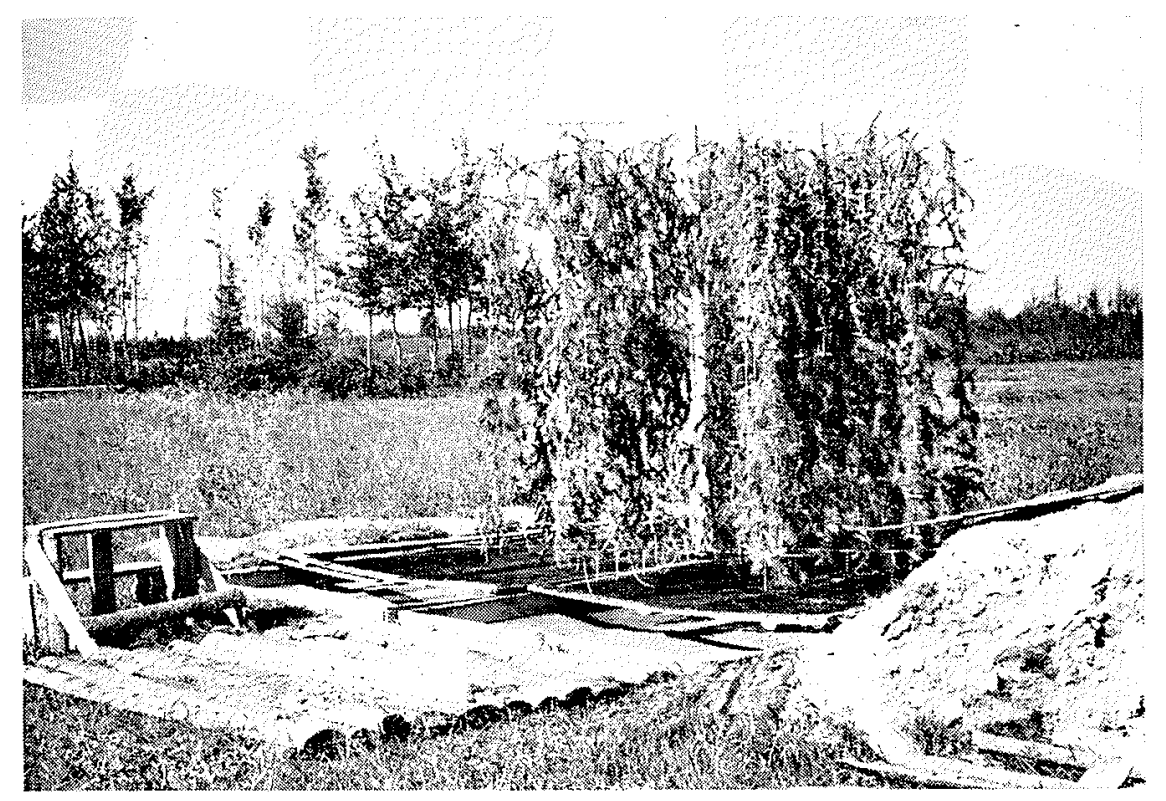

FIGURE 3. The "Carrousel" in operation; 


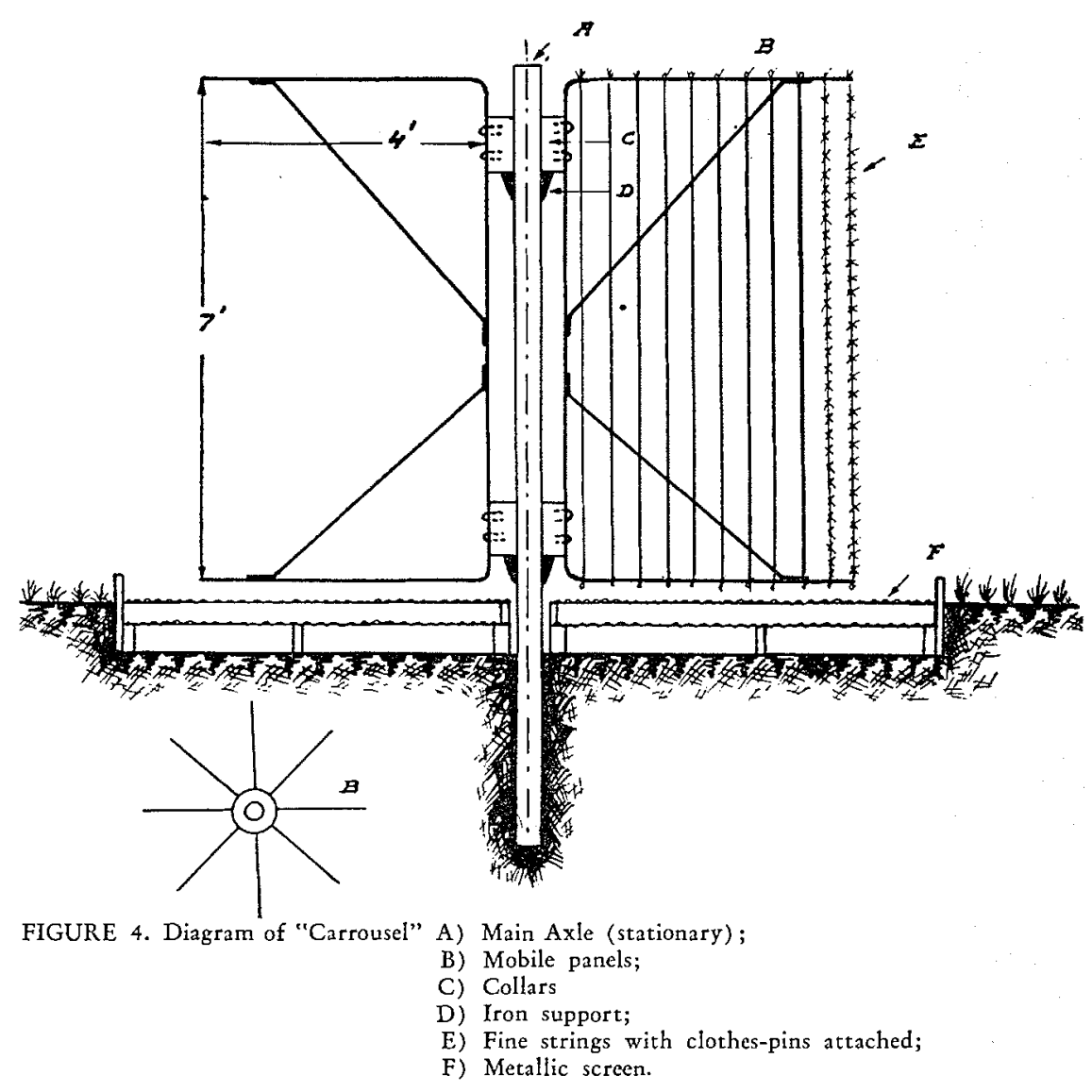

most efficient method, in terms of man-hours, is by collecting only from small trees, measuring from 6 to 10 feet in height, along roadsides or in exposed areas in the stands where populations of the insect tend to concentrate. Small branches with larval colonies are clipped and placed in large cardboard boxes. Collections should be made late in July when larvae are in their second instar, since the insect appears to be most susceptible to virus infection at this stage (Smirnoff, 1961). In a heavy $N$. swainei infestation one man should be able to collect 100,000 to 150,000 larvae in eight hours. To avoid subsequent complications in the rearing process it is important that collections be made in less than three days.

\section{REARING AND INFECTING LARVAE}

After testing various methods for infecting larvae, the following were found satisfactory from the point of view of quality, quantity, and simplicity of pathogen production. 


\section{a) Indoor Rearings}

The rearing room should be equally lighted throughout to prevent larvae from migrating toward the source of light. Collected twigs bearing larvae are placed in wooden racks $(5.5 \times 2.5 \times 0.8$ feet $)$ with 16 -mesh wire screen at the bottom (Fig. 2). Each rack, which holds approximately 1200 twigs (75,000 larvae), is placed 10 inches above the floor on wooden blocks. Room temperature should be maintained between $25^{\circ}$ and $30^{\circ} \mathrm{C}$. The first spraying of the larvae should be done with a virus suspension ${ }^{3}$, at a concentration of one million pol./ml., applied with a portable pressure sprayer at the rate of $50 \mathrm{ml}$. of solution per rack. It is necessary to stir the suspension before each spraying to prevent settling of polyhedra.

During the first eight days it is necessary to perform the following operations two or three times each day: remove twigs stripped of their needles; rap the racks to liberate the faeces; add fresh foliage (spraying it each time with virus). Sprayings are discontinued after this period as the infected larvae virtually stop feeding and show a tendency to migrate and group along the inside or outside of the racks. During this migration it is occasionally necessary to return the larvae to the foliage. Ten to twelve days after the beginning of treatment the larvae change from a greenish to a lemon yellow colour. At this point mortality has started and /it is necessary to remove affected larvae just before their death or immediately after, since one or two days later they decompose and liquefy with a resulting loss of virus material. The dying larvae are collected with smooth forceps or small brushes and are placed in glass containers with a little water, crushed and stored several days at room temperature to allow further decomposition.

b) Outdeor Rearings ("Carrousel" method)

In an attempt to develop a method approximating natural conditions for the sawfly, an apparatus was developed which can be set outdoors (Fig. 3) to rear approximately $500,000 \mathrm{~N}$. swainei larvae at one time. This device consists of a number of strings stretched vertically between pairs of horizontal arms rotating on a fixed central axle (Fig. 4). Jack pine foliage, with $N$. swainei colonies, is attached with clothes pins along the strings. Screened trays under the apparatus trap the falling larvae and permit frass to fall through to a lower level. Since the larvae migrate to the sunny side of the apparatus, it is rotated frequently during the day to prevent larvae from concentrating on one side. The foliage is replaced each day. As with the indoor rearing method, the virus suspension is sprayed on the foliage once each day during the first five to eight days of rearing. Dead larvae, falling on screens and retained on foliage, are removed at each inspection and placed in water, in glass containers, as described previously.

The indoor rearing method is more reliable than the outdoor method a it does not depend on atmospheric conditions which can retard development of the disease. On the other hand, the "carrousel" method is less difficult to use and is less expensive as it does not require as much daily attention.

Preparation and Storage of Pathogen

The purification of viral polyhedra is a long and delicate operation which

${ }^{8}$ A limited amount of virus is presently available, for production purposes, from the Forest Entomology and Pathology Laboratory of the Dept. of Forestry of Canada, Quebec. 
can be executed only in specially equipped laboratories, while the rough preparation of the pathogen as described herein, can be easily done even under field conditions or where insects are reared. The dead larvae collected from mass rearings are crushed with a wooden pestle in a glass or plastic container. One part of crushed larvae is mixed with three parts of water and the mixture is left standing for several days to allow decomposition before filtration. Three separate filtrations are needed: the first is made through cheese cloth; the second through a double thickness of cheese cloth; and the third through a fine nylon cloth. Since the deposit after the third filtration still contains many polyhedra, it is stored at room temperature for several days in two parts of water, stirred and crushed daily, then filtered again three times as described above. A third extraction can still be made from the resulting deposit through the same procedure. Filtrates are stored together in darkness in thick glass or polyethylene bottles, preferably at a temperature around $4^{\circ} \mathrm{C}$. Usually the pH of this filtrate is from 6.0 to 7.0 . (pH 4.0 to 5.0 and 8.0 to 8.5 are critical, and may cause the polyhedra to dissolve). Under such conditions, the polyhedral virus suspension can be kept for several years without appreciable inactivation (Neilson and Elgee, 1960). The filtrate suspension is usually of a brownish colour, but after settling the polyhedra form a white layer at the bottom of the bottle. It should be emphasized again that the suspension must be thoroughly mixed before diluting. Normally 100,000 virus-killed larvae makes about 13 litres of polyhedral suspension, at a concentration of 50 million to 100 million polyhedra per ml., while the concentration used for the spraying is between one million and two million polyhedra per ml., depending on the type of application. To obtain the polyhedra used in these suspensions, the filtrates obtained are centrifuged at 9000-10,000 rpm. for one hour, and the deposit mixed with an equal quantity of Bentonite powder. This mixture can then be pressed out in the form of small tablets, spread on a smooth surface and dried, or crushed with a mortar and pestle and kept in a closed container in a powdered state. The optimum temperature for storage is about $4^{\circ} \mathrm{C}$. and in the powdered state this pathogen will keep its potency for several years. If centrifugation is not practical the filtrates can be placed in large bottles and left to settle for one month. The clear liquid is then siphoned, and the deposit mixed with Bentonite as described above.

Precise concentration of polyhedra in the stock must be determined by specalists with the help of a dark-field microscope and a counting chamber. Such a concentration must be accurately established before necessary dilutions can be made for practical application.

\section{Methods of Application}

The Pathogen as a Biological Agent of Control

Large quantities of virus polyhedra are not available on the market but in areas where the sawfly exists in outbreak proportions and larvae can be collected in quantity, it is possible to obtain and maintain the necessary inoculum through the procedures mentioned above. Three methods are suggested for using the virus against $N$. swainei. Each method is feasible and can be justified according to the needs and objectives to be realized. 


\section{First Method: Complete spraying}

For fast results in regions severely infested by the insect, it is recommended that the stand be totally sprayed with 0.5 gallons per acre of a suspension containing 1 million polyhedra per $\mathrm{ml}$. This will give $100 \%$ larval mortality after 15 to 20 days (Smirnoff, Fettes, Haliburton, 1962). However this method cannot be recommended for use in vast forest areas as yet due to the large quantities of pathogen material required.

\section{Second Method: Spot or strip spraying}

This method is used to create spot (epizooty) in N. swainei populations which progressively develops into a general condition. It is estimated that with this method, the final effect will be attained within three or four years (Smirnoff, 1962). Under most conditions this would be an effective and economical method.

\section{Third Method: Preventive}

This involves the introduction of the virus disease in the sawfly population by spraying low dosages of the virus $(100,000 \mathrm{pol} . / \mathrm{ml})$, during the period when larvae reach the fourth instar. Introduction of $N$. swainei cocoon containing larvae infected with sub-lethal dosages of the virus would also be effective. The adult females transmit the infection to their progeny, creating centers of epizooty (Smirnoff, 1962).

Approximate Cost of Production of Pathogen

From information obtained in our experiments it was determined that the rearing of one million sawfly larvae and the subsequent preparation of pathogen, amounted to from $\$ 500.00$ to $\$ 600.00$, including salaries and supplies. The virus preparation thus obtained yielded approximately 3,250 gallons of spray suspension at concentrations between 0.5 and one million polyhedra per ml. With the material obtained it should be possible to cover from 3,250 to 5,000 acres of forest stands with a dosage of 0.5 to 1.0 gallon per acre, when immediate control is required. When spraying in spots or in strips, it is possible to cover much larger areas.

In the light of the results which have been obtained up to now on the experimental application of $N$. swainei virus for the biological control of this insect, it is felt that the virus can be a valuable tool in keeping the insect population in check.

\section{ACKNOWLEDGMENT}

The author wishes to express his gratitude to Dr. L. Daviault, Officer-inCharge, Forest Entomology and Pathology Laboratory, Quebec, for his encouragement. Also he thanks Drs. R. J. Finnegan and G. B. Ouellette of the same laboratory for revising the manuscript.

\section{REFERENCES}

NEILSON, M. M. and ELGEE, D. E. 1960. The effect of storage on the virulence of a polyhedrosis virus. J. Ins. Path. 2: 165-171.

SMIRNOFF, W. A. 1960 . Observations on the migration of larvae of Neodiprion swainei Midd. (Hymenoptera: Tenthredinidae). Can. Ent. 92: 957-958.

SMIRNOFF, W. A. 1961. A viral disease of Ncodiprion swuainei Midd. J. Ins. Path. 3: 23-46.

SMIRNOFF, W. A. 1962. Trans-ovum transmission of virus of Neodifrion swainei Midd. (Hymenoptera: Tenthredinidae). J. Ins. Path. 4; 192-200.

SMIRNOFF, W. A., FETTES, J. J. and HALIBURTON, W. 1962. A virus disease of Swaine's Jack pine sawfly, Neodiprion swainei Midd, sprayed from an aircraft. Can. Ent. 94: 477-486. 